\title{
sciendo
}

\section{The CONNECTION BETWEEN CORPORATE SOCIAL RESPONSIBILITY AND CORPORATE RESPECT FOR HUMAN RIGHTS}

\author{
Ana Čertanec ${ }^{1}$
}

\begin{abstract}
The purpose of this article is to study the connection between corporate respect for human rights and corporate social responsibility. The author argues that business entities have a responsibility to respect human rights and that this responsibility forms part of their corporate social responsibility. The author defends the view that business and human rights issues are distinct from corporate social responsibility issues in their legal nature and content, while the strategic approach in the implementation of these concepts is the same. The author further examines whether voluntary corporate social responsibility initiatives include human rights, and how society understands the connection between the two. The conclusions of the article shed light on the interconnection between these two terms.
\end{abstract}

\section{Keywords}

Business and Human Rights, Corporate Respect for Human Rights, Corporate Social Responsibility, CSR Initiatives, Human Rights

\section{Introduction}

Corporate social responsibility (CSR) is normally defined as a concept whereby business entities voluntarily incorporate social, environmental and ethical standards into their operations in order to improve the lives of employees, the local community and society as a whole. The concept of CSR is based on the view that business entities should consider broader social goals in their activities, rather than just financial ones. ${ }^{2}$

The goal of generating profit has been supplemented with broader social goals, such as maintaining long-term stability, maintaining internal stability, promoting development, protecting the interests of all stakeholders, engaging in activities with and protecting the interests of the broader social community, and respecting human rights. ${ }^{3}$

\footnotetext{
${ }^{1}$ University of Ljubljana, Kardeljeva ploščad 17, 1000 Ljubljana. E-mail: ana.certanec@ef.uni-lj.si.

${ }^{2}$ As early as 1993, Korže stated that entrepreneurial liberalism was permissible, but had to be in accordance with social principles.

${ }^{3}$ Korže (2014).
} 
Human rights are rights intended for an individual and the protection of his or her values. Wettstein (2009) says that human rights 'secure the moral minimum necessary for us to live a liveable, dignified life as human beings'. When the international human rights regime was set up, states were designated as the sole duty-bearers and the only subject that could violate international human rights law. ${ }^{4}$ This has changed over time, and now the subject of international human rights law is deemed 'anyone who is the bearer of rights and duties in international law and is subject to the international legal order' ${ }^{5}$ It is no longer only states that have obligations in the area of human rights protection, but also non-state actors and among them business entities. ${ }^{6}$ Business entities have a responsibility to respect human rights.

Therefore, the question about the connection between CSR and corporate respect for human rights is raised. Unambiguously, the respect for human rights forms part of CSR. While CSR has been gaining global importance, business and human rights (BHR) issues have been neglected. Business entities have acknowledged their social responsibility and adopted CSR policies without being aware as to what CSR actually includes. Human rights are normally considered a completely different topic that results in actual problems relating to the implementation of the appropriate CSR strategy. The adoption of UN Guiding Principles on Business and Human Rights (UN GPs) ${ }^{7}$ and the increased focus on corporate respect for human rights have perfect timing to acknowledge the connection between them. Business entities should not consider these questions separately but comprehensively and integrated them as only in this way an appropriate CSR strategy can be prepared.

The main focus of this article is the extent to which the BHR issues are distinct from the CSR issues. This question is significant, because the CSR issues have a tendency to crowd out the BHR issues. The author believes that the BHR issues are distinct from the CSR issues in their legal nature and content, while the strategic approach in the implementation of these concepts is the same. The author explains the role of various legal, including socio-legal theory approaches to CSR and brings in the emergent theory on business and human rights as an interdisciplinary field. The aim is to discuss some issues that arise from the manner that the CSR and human rights respect interact, with particular emphasis on the review of CSR initiatives from the perspective of human rights.

In the initial chapters, the author presents the basic theoretical findings of CSR and of BHR on which a further analysis can be carried out. The aim is to provide a theoretical contribution by contextualizing this data in light of the main debates and theories put forward by CSR and BHR scholars. Then the author studies the connection between the CSR and corporate respect for human rights and examines to which extent the BHR issues are distinct from the CSR issues by integrating the emergent legal theory and norms. The

\footnotetext{
${ }^{4}$ Economic and Social Council (2006, para 9).

${ }^{5}$ Letnar Černič (2003).

${ }^{6}$ International organisations such as the World Bank, the World Trade Organization, NATO, etc., are also important duty-bearers in the field of human rights protection but have been intentionally omitted from this paper, since the focus here is entirely on business entities.

${ }^{7}$ Human Rights Council (2011).
} 
author further examines whether voluntary CSR initiatives include human rights, and how society understands the connection between them.

\section{Corporate social responsibility}

There are many definitions of CSR. ${ }^{8}$ A renewed EU Strategy 2011-14 for Corporate Social Responsibility ${ }^{9}$ defines it as 'the responsibility of enterprises for their impacts on the society'. Letnar Černič (2009) defines CSR as the 'continual commitment of a business enterprise to respect fundamental human rights, ensure the rule of law, prevent corruption, protect the environment, act ethically, pursue economic development, and improve the quality of life for employees, the local community and society as a whole'. Buhmann (2011) sees it as private or public companies taking action 'to mitigate or prevent a negative social and environmental impact or to maximise a positive impact, generally beyond the obligations of directly applicable statutory law'. Steiner and Steiner (2003) define it as a 'duty a corporation has to create wealth using means that avoid harm to, protect, or enhance societal assets'. Making profit is not the only goal of a business entity: its performance is not judged only by its ability to meet the needs of its customers, but also by the manner, it meets the needs of its employees, non-government organisations, local community representatives, and other groups. ${ }^{10} \mathrm{CSR}$ applies to all activities throughout the supply chain. Business entities express and demonstrate their socially responsible approach in the form of value statements, codes of conduct and non-financial reports.

At first CSR was not thought to have any legal implications, but then a number of cases before the US courts found that business entity's impacts on labour rights, human rights and the environment were indeed of legal relevance. ${ }^{11}$ There are three different views of the legal status of CSR: ${ }^{12}$

$*$ it is a legal requirement;

$*$ it is not a legal requirement;

* it is a requirement based on social and normative pressure only.

In 2001, the Commission of the European Communities defined CSR as 'a concept whereby companies integrate social and environmental concerns in their business operations and in their interaction with their stakeholders on a voluntary basis', but at the same time it emphasised that CSR was not 'a substitute for regulation or legislation concerning social rights or environmental standards' (para 20, 22). It defined CSR as 'not only fulfilling legal expectations, but also going beyond compliance' (para 21). In 2006, the Commission of the European Communities explicitly stated that CSR was only voluntary. Even though the EU in 2011 revised its definition of CSR and deleted the previous reference to a 'voluntary' action or action 'beyond the requirements of the law', the majority view that CSR is not a legal requirement.

\footnotetext{
${ }^{8}$ In both theory and practice, terms such as corporate citizenship, corporate sustainability, etc., are also used.

${ }^{9}$ European Commission (2011).

${ }^{10}$ Pedersen and Andersen (2006).

${ }^{11}$ Buhmann (2011).

12 Ibid.
} 
Buhmann (2006) rejects this view and asserts that CSR acts as informal law and is based on a set of fundamental principles of law. Buhmann (2011) attributes the confusion about the nature of CSR to its having been defined as actions that go beyond legal requirements, since this definition created the damaging idea that CSR and the law are distinct from each other. ${ }^{13}$ For Buhmann (2011) CSR encompasses compliance with the law, because in order to go beyond the law, it is first necessary to comply with it. Wettstein (2009), too, argues that the statement about the voluntary nature of CSR was incorrect, and concludes that, while there are many claims about its voluntary status, these lack substantiation. He attributes the misinterpretations of the nature of CSR to the fact that, when the term first began to be used, it generally referred simply to the making of charitable donations to the community. ${ }^{14}$ It is obvious that even business entities that support their local communities with donations can act in socially irresponsible ways, if for example they violate workers' rights, harm the environment or take any other socially irresponsible actions. ${ }^{15}$ Also all Caroll's models of CSR include conforming to the law in the responsibilities of CSR, i.e. CSR includes legally mandated actions and not just actions that go beyond the requirements of the law. ${ }^{16}$

For the purpose of the debate on the legal status of CSR it is also important to point out the distinction between the 'explicit' and 'implicit' CSR. Matten and Moon (2008) refer to the explicit CSR, that is characteristic of the United States, as voluntary programmes and strategies by business entities that assume and articulate their social responsibility and do not reflect any broader formal or informal institutions. On the other hand, the implicit CSR, that is characteristic of Europe, emphasizes business entities' social role within the wider formal and informal institutions that define mandatory and customary requirements to address social issues for all business entities. ${ }^{17}$ The difference in the style of CSR is therefore the reason why in the United States CSR is seen as purely voluntary, while in Europe CSR can be considered a legal requirement. European business entities are obliged to assume wider responsibilities than American entities do and therefore they do not need any independent corporate responsibility for issues of such societal concern. ${ }^{18}$

To conclude, opinions on the legal status of CSR vary. CSR goes beyond mere compliance with the law, but is based on the assumption that the business is already operating according to the national social and environmental legislation (i.e. fulfilling its legal obligations). Therefore, the author believes that CSR cannot be viewed as solely voluntary as some of its aspects are legally mandated. The legal status of CSR also depends on the social issue. Some issues of CSR have already been legally regulated in some states (i.e. labour rights) and consequently there is a strong relationship between CSR and law. Some aspects are a legal requirement, some are not. Nonetheless, even if they are not, they are mostly at least a requirement based on social and normative pressure.

\footnotetext{
${ }^{13}$ Wettstein (2009) shares this view, and sees it as a consequence of a poor understanding of ethics.

${ }^{14}$ Wettstein (2009).

15 Ibid.

${ }^{16}$ Caroll (1979); Caroll (1991); Schwartz and Caroll (2003).

${ }^{17}$ Matten and Moon (2008).

${ }^{18}$ Ibid.
} 


\section{Human rights and business}

There is no uniform definition of human rights, ${ }^{19}$ but all versions agree that human rights arise from human dignity. All emphasise that human rights are universal, indivisible, interdependent and interrelated; ${ }^{20}$ in addition, International Standard ISO $26000^{21}$ also states that they are both inherent and inalienable. Humans have human rights by their very nature, and these rights are therefore deemed to belong to the individual; consequently, every individual is entitled to enjoy them without discrimination. ${ }^{22}$ Korže (2006) argues that human rights are one of the fundamental ways of understanding modern economic, political and legal systems and procedures, since a person's individual and collective nature derives from their human rights.

When the international human rights regime was set up, states were designated as the sole duty-bearers and the only subject that could violate international human rights law. ${ }^{23}$ This is why the duty to respect, protect and fulfil human rights, as laid down in international human rights documents, only applies to states. ${ }^{24}$ This has changed over time, and now the subject of international human rights law is deemed 'anyone who is the bearer of rights and duties in international law and is subject to the international legal order' ${ }^{25}$ It is no longer only states that have responsibilities in the area of human rights protection, but also non-state actors and among them business entities. Business entities undoubtedly have an indirect obligation to respect human rights, ${ }^{26}$ because as Ruggie (2013) argues international law requires states to adopt appropriate legislation ensuring that non-state actors, business entities included, do not violate recognised human rights. The author shares the majority view $^{27}$ that, although business entities are not specifically required by binding international legislation to respect human rights, they are nevertheless under a direct obligation to do so. ${ }^{28}$ Cragg (2012) and Arnold (2010) argue that although corporate respect for human rights is not internationally legally sanctioned, it is not voluntary, but a non-discretionary corporate moral obligation. Wettstein (2012) also emphasizes the moral dimension of corporate responsibility to respect human rights, seeing that the responsibility that is grounded only in a legal, political or strategic understanding of human rights suffers from substantial shortcomings. As Arnold (2010) argues, the existence of business entities' obligations does in no way diminish the need for state human rights protection as human rights regime needs all agents and institutions to respect human rights. Hsieh (2015) argues that business entities do not have direct human rights obligations on the grounds of status egalitarianism, but they do have these obligations based on other grounds.

\footnotetext{
${ }^{19}$ Throughout this article, 'human rights' is used in the sense of human rights and fundamental freedoms.

${ }^{20}$ World Conference on Human Rights (1993).

${ }^{21}$ International Organization for Standardization (2010), para 6.3.2.1.

22 Ruggie (2013), McBeth (2010).

${ }^{23}$ Economic and Social Council (2006, para 9).

24 Van Huijstee et al (2012).

25 Letnar Černič (2003).

${ }^{26}$ Bilchitz (2013).

${ }^{27}$ Muchlinski (2001), Letnar Černič (2011), De la Vega and Mehra (2009).

${ }^{28}$ More about the reasons in Wettstein (2012).
} 
The responsibility of business entities to respect human rights applies to all internationally recognised human rights, ${ }^{29}$ since business entities can have a direct or indirect effect on virtually any human right. ${ }^{30}$ In developed countries the majority of these rights are already enshrined in law (i.e. employment legislation, social protection legislation, criminal legislation, etc.), while in developing countries they have not yet been adequately enacted. The goal is that business entities in every United Nations (UN) member state should be uniformly accountable for human rights abuses, regardless of national legislation.

As many theoreticians ${ }^{31}$ argue business entities can make a positive contribution to the enjoyment of human rights, but equally, they can have adverse effects on human rights protection, and cause the rights of individuals and groups to be abused. They can abuse the human rights to health, adequate food, privacy and non-discrimination, as well as labour rights, etc. Corporate respect for human rights is about observing at least minimum standards for human existence. ${ }^{32}$ Business entities have a direct responsibility to respect human rights throughout their operations, regardless of national law or enforcement of such law as this constitutes a 'necessary cost of doing business' as Arnold (2010) calls it. All potentially affected stakeholders are protected against human rights abuses. The main stakeholders are the employees of the business entity, but employees of business partners, customers, inhabitants of the local community, etc., are also entitled to the protection.

The protection of human rights in business is mostly governed by non-binding policies, ranging from recommendations issued by international organisations to an individual business's internal code of conduct. Numerous attempts have been made to secure the adoption of an international legal instrument that would impose a duty on business entities to protect human rights (e.g. UN Norms on the Responsibilities of Transnational Corporations and Other Business Enterprises with Regard to Human Rights ${ }^{33}$ ). So far every attempt to impose obligations has failed and only voluntary initiatives such as the OECD Guidelines for Multinational Enterprises ${ }^{34}$ and International Standard ISO 26000 have been successful. The most recent non-binding recommendations are the UN GPs adopted in 2011. These clearly define the tasks of both states and business entities in the field of human rights protection in a business context. While these principles are only guidelines, its language suggests obligations and not recommendations. The state has a duty to protect human rights from abuses by third parties; business entities have a responsibility to respect human rights, which includes avoiding infringing the human rights of others and addressing adverse human rights impacts. Both states and business entities are required to give victims access to effective remedy should an abuse occur.

\footnotetext{
${ }^{29}$ On the contrary, Arnold (2010) is of the opinion that a set of basic human rights is more appropriate.

${ }^{30}$ United Nations: Office of the High Commissioner for Human Rights (2012).

${ }^{31}$ Soh (2013), Monshipouri et al (2003), Weissbrodt (2005), Ruggie (2013), Kinley and Tadaki, (2003-2004).

${ }^{32}$ Wheeler (2015).

${ }^{33}$ E/CN.4/Sub.2/2003/12/Rev.2 (26 August 2003).

${ }^{34}$ OECD (2011).
} 


\section{Link between CSR and human rights}

As previously stated, CSR is a concept whereby business entities voluntarily incorporate social, environmental and ethical standards into their operations. Business entities are responsible for their impacts on society and therefore have a duty to consider not only financial, but also broader social goals. One of these social goals is undoubtedly the respect for the rights of stakeholders affected by their activities. The respect for human rights is therefore an essential component of CSR. This is confirmed in paragraph 52 of the Green Paper: Promoting a European Framework for Corporate Social Responsibility ('Corporate social responsibility has a strong human rights dimension') and chapter 3.3 of A renewed EU Strategy 2011-14 for Corporate Social Responsibility ('CSR at least covers human rights'). Ruggie (2013), too, believes that CSR includes human rights; he views slower progress in this area because of greater emphasis on the environment and other social issues. Carasco and Singh (2008) regard the inclusion of human rights responsibilities in corporate codes of conduct as the most dramatic step forward on the path to CSR. Rabet (2009) also thinks human rights form part of CSR: she sees CSR as 'a form of voluntary self-regulation by corporations, which, amongst other things, claims to bring the protection and promotion of human rights onto the corporate agenda'. Buhmann (2011), too, considers human rights to be part of CSR and argues that they feature prominently in the CSR policies and philosophies of many Nordic and European business entities. She further states that corporate responsibilities for human rights and labour rights are often included in CSR under the heading of 'social issues'. ${ }^{35}$ Wettstein (2009) is also of the opinion that 'no plausible conception of CSR can turn a blind eye on corporations' human rights obligations', regardless of the fact that human rights concerns have not traditionally been seen as part of CSR. Ramasastry (2015) describes a link between CSR and human rights like 'two close cousins' - they are two different but overlapping concepts, focused on business entities engaging in responsible and socially beneficial activities. Emeseh and Songi (2014) link CSR with human rights, but surprisingly do not link human rights with legislation.

From all the facts mentioned above it is clear that CSR and human rights are interconnected. The key question is to which extent the BHR issues are distinct from the CSR issues and whether CSR clouds the BHR issues. The author believes that the BHR issues are distinct from the CSR issues in their legal nature and content, while the strategic approach is the same. Therefore, the author further examines the difference between CSR and corporate respect for human rights regarding the law, strategic approach in the implementation of these concepts and the content. The analysis leads to the conclusion if the proposed hypothesis is correct or not.

${ }^{35}$ Buhmann (2011). 


\section{The Difference between CSR and Corporate Respect for Human Rights Regarding the Law}

The purpose of CSR is not simply to fulfil legal expectations, but to make positive contributions to human capital, the environment and relations with stakeholders, beyond mere compliance with the law. ${ }^{36}$ It is left to an individual business to decide whether to adopt CSR policies ${ }^{37}$ The actual level of CSR is completely dependent on the culture of the organisation and the extent of its ethical leadership. Often CSR is nothing more than a cosmetic exercise, without any real significance. ${ }^{38}$

On the other hand, human rights respect is mostly seen as a matter of legal compliance. ${ }^{39}$ Buhmann (2006) argues that human rights present 'a principle of law underpinning more specific norms, feature as the basic foundation for international and national specific human rights standards, EU references to ILO core labour standards as a recommended minimum for corporate action in the developing countries, and for law in the makings'. They have a real significance, as they are values that guide business behaviour.

While CSR is seen as a voluntary responsibility and corporate human rights responsibilities as mandatory (at least in an indirect way, if not even in a direct way) business entities do not perceive human rights as a part of CSR. Because CSR for them is something voluntary, human rights fall out of scope of their perception of CSR. If there would be clear evidence that a part of CSR is voluntary and a part of it mandatory, linking these terms would be significantly easier. Compliance with internationally recognised legal standards is a basic requirement for CSR, for which voluntary initiatives can be no substitute. ${ }^{40}$

For example, one of the human rights is a right of fair wage. The amount above fair wage determined by the law of the State is considered a good CSR policy, as there is no legal duty to pay more than a statutory minimum wage. This is an example of going beyond legal compliance, but also including legal compliance. A statutory minimum wage is a legal standard and anything higher is a social standard. On the other hand, CSR and human rights coincide in ensuring safe and healthy working conditions. Passing and enforcing proper working conditions is a legal and social standard. Lastly, human rights and CSR do not coincide in philanthropy, as this is only a social standard.

The BHR issues are therefore distinct from the CSR issues as they are narrower than the CSR issues. The CSR issues are going beyond legal compliance, but also include legal compliance, including the BHR issues. Business entities have a difficulty in understanding this, as there is so much emphasis on voluntary aspects of CSR. It would be necessary to increase awareness of the interconnection between these two issues, as the lack of this is harmful for the potentially affected stakeholders.

\footnotetext{
${ }^{36}$ Commission of the European Communities (2001, para 21); Taylor (2011).

${ }^{37}$ Wheeler (2015).

${ }^{38}$ Porter and Kramer (2006).

${ }^{39}$ Obara's empirical study on interpretation and management of human rights in 22 large UK business entities showed that business entities recognize human rights as containing a legal and mandatory element. See Obara (2017).

${ }^{40}$ See Lund-Thomsen (2008).
} 


\section{The Difference between CSR and Corporate Respect for Human Rights Regarding the Content}

CSR and respect for human rights are viewed as two different concepts. While CSR is comprised of imperfect, positive and special duties, human rights are perfect, negative and universal moral obligations on business entities. ${ }^{41}$ CSR is often viewed as a business's positive contribution to society, as "corporate responsibilities beyond the (negative) realm of doing no harm' ${ }^{42}$ It is comprised of activities that are regulated by law (i.e. labour issues, environmental issues) and activities that are voluntary (donations, sponsorship). As Ramasastry (2015) argues, CSR focuses on corporate governance and decision-making.

On the other hand, human rights are perceived to deal with the negative aspects of business activity. Business entities have to do no harm, with the state watching over them to hold them accountable if they do not act accordingly and providing access to remedies for victims of human rights abuses. ${ }^{43}$ However, in the frame of corporate responsibility to respect human rights are not only omissions of behaviour that could lead to human rights violations, but also activities to ensure human rights respect by carrying out human rights due diligence. According to UN GPs, business entities have the responsibility to respect human rights by taking steps to prevent and mitigate adverse human rights impacts and refrain from actions that could lead to human rights abuses. If human rights abuses should occur despite these steps, it is their duty to take remedial action. Some ${ }^{44}$ argue even broader business entities' obligations that extend to proactive company involvement in the protection and realization of human rights. According to this positive aspect, business entities' role in the society is the reason for their promotion of human rights respect and not only for the prevention of business related human rights violations. Wettstein (2012) argues that limitation of corporate obligation to mere non-violation (the so called 'human rights minimalism') could be the reason why many of the human rights issues that CSR scholars are regularly dealing with, have been addressed only in the manner of philanthropy and charity and not as a legal obligation. The author does not share the view on broader business entities' obligations, as this is the role of the state, ${ }^{45}$ but agrees that if the terms were more publicly linked, this could lead to a win-win situation for CSR and human rights respect. In this way, CRS would gain importance as not only voluntary, but also mandatory, while on the other hand human rights issues would receive higher awareness and therefore their respect would increase.

The content of CSR issues is undoubtedly broader than of that of BHR issues as CSR has a focus on proactive activities for the wellbeing of society, while the BHR issues are focused on having a positive process of human rights due diligence to ensure respect for human rights. The BHR issues are a part of the CSR issues, but unfortunately, this is ordinarily overlooked, because too much attention is paid on CSR proactive activities, while neglecting its legal compliance component.

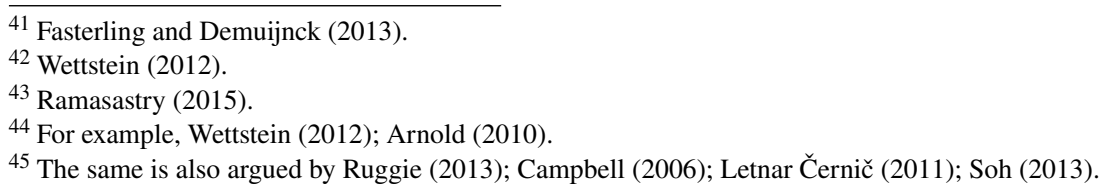




\section{The Difference between CSR and Corporate Respect for Human Rights Regarding the Strategic Approach}

According to McCorquodale (2009) CSR policies and human rights operate in fundamentally different ways. As a rule, CSR is managed strategically. Business entities have strategies on how to incorporate social, environmental and ethical standards into their operations and communicate this approach explicitly. They have in place policies and procedures to ensure social responsibility and to annually report on their progress. CSR has become a strategy for increasing profit. CSR also manages some human rights issues, but does not explicitly present them as such.

Human rights issues are managed more implicitly. Business entities have to avoid infringing the human rights of others, mostly by respecting national legislation. Corporate responsibilities to respect human rights have not been a part of business strategy, but only one of the compliance issues. This has changed with the adoption of the UN GPs that claim that business entities have the responsibility to respect human rights by having in place policies and processes appropriate to their size and circumstances. According to the second pillar of UN GPs business entities should express their commitment to respect human rights through a statement of policy and carry out human rights due diligence process through assessing actual and potential human rights impacts, integrating and acting upon the findings, tracking responses, and communicating how impacts are addressed. According to UN GPs, business entities should 'know and show' that they respect human rights. The consequence of the UN GPs is that now also for human rights the explicit strategic approach has been put into effect. In their study of practices of business entities worldwide in attempting to implement human rights due diligence McCorquodale, Smit, Neely and Brooks (2017) found that there are still great shortcomings in identification, implementation and responding to human rights impacts across all business entities.

Previously CSR and human rights had different approaches and therefore the two terms were not sufficiently linked. With the adoption of the UN GPs and its human rights due diligence, a similar strategic approach has been developed. CSR and corporate respect for human rights have to be known internally and shown externally and form a part of business decisions. In both cases it must become a part of their strategic decisions, all employees and shareholders should be aware of it and consider it in their business decisions. ${ }^{46}$ Only in this way will it be possible to prevent that voluntary CSR activities (sponsorship, donations) do not cloud the BHR issues. ${ }^{47}$ Corporations can be quickly induced that by engaging in philanthropy or sponsorship they weaken its commitment to uphold its human rights responsibilities. As Obara and Peattie (2017) emphasise there is a danger that without the explicit and visible presence the human rights principles and goals become lost within the CSR structures, processes and language.

\footnotetext{
${ }^{46}$ Integrating human rights within business strategies has demonstrated as an extremely difficult and timeconsuming processes with high organisational costs, even if businesses are committed to doing so (Institute for Human Rights and Business, 2011); Arkani and Theobald (2005).

47 Arkani and Theobald's research (2005) suggests that business entities rather involve in the provision of general support for welfare programmes than to more high-risk direct intervention in human rights issues.
} 


\section{Analysis}

From all the facts mentioned above it is evident that the BHR issues are distinct from the CSR issues in their legal nature and content. The BHR issues are mandatory, while the CSR issues are mandatory only in the part where business entities should comply with the regulations and other parts are voluntary. The BHR issues are meant to prevent and mitigate adverse human rights impacts and refrain from actions that could lead to human rights abuses, while the CSR issues are, in addition to legal compliance, also intended for proactive company involvement to help improve welfare. As CSR is broader than BHR issues, it is necessary to be cautious so that BHR issues are not clouded.

On the other hand, the strategic approach is the same; the distinction originates only from the difference in the content. Therefore, business entities should have strategies on how to include the CSR and BHR issues in their operations. Acknowledging of the CSR and BHR issues has to become a part of their business decisions, everyone in the business entities should be aware of the importance of these two issues and accept their decisions based on them.

With regard to the findings, the author will now study the specific CSR initiatives regarding the law, content, and strategic approach in the implementation of these concepts and attempt to find whether the findings stated in this chapter are correct.

\section{CSR initiatives that include human rights}

For a long time global CSR initiatives did not focus on human rights, but only mentioned them in passing. In 1983, the UN Draft Code of Conduct on Transnational Corporations ${ }^{48}$ prescribed that transnational corporations should respect human rights and fundamental freedoms in the countries in which they operated (para 13). The OECD Guidelines for Multinational Enterprises, UN Global Compact Principles ${ }^{49}$ and other initiatives on CSR also had superficial commitments to respect human rights, without specific policies to ensure they were implemented in practice. The good news is that in the last few years many initiatives (such as the OECD Guidelines for Multinational Enterprises, UN Global Compact Principles, and ISO 26000) have been updated with chapters on human rights. In addition, the Global Reporting Initiative (GRI) has devoted a whole GRI Sustainability Reporting Standard to human rights - GRI 412: Human Rights Assessment $2016^{50}$ sets out the reporting requirements for human rights assessments. There are also other GRI Standards dealing with individual human rights: for example, GRI 406: Non-discrimination 2016, GRI 407: Freedom of Association and Collective Bargaining 2016, GRI 402: Labour/Management Relations 2016, GRI 411: Rights of Indigenous Peoples 2016. ${ }^{51}$

It is also important to mention the national law regulation on CSR. Countries are always more in favour of CSR regulation. In 2013, India in its Companies Act prescribed a mandatory CSR spend of at least two per cent of the average net profits made during the

\footnotetext{
${ }^{48}$ E/1983/17/Rev. 1 (21 May 1983).

${ }^{49}$ UN Global Compact (2017a).

${ }^{50}$ GRI (2019).

${ }^{51}$ GRI (2017).
} 
three immediately preceding financial years on all companies meeting specified financial thresholds (Section 135/5). In 2014 the European Union (EU) Directive 2014/95/EU prescribed mandatory CSR reporting for large public-interest undertakings, whose balance sheets showed an average of more than 500 employees during the financial year. The EU member states therefore have had to implement in their national law the requirements on the mandatory CSR reporting by 6 December 2016. France went even a step further and adopted the law that specifically regulates human rights impacts on business. The French Corporate Duty of Vigilance Act 2017 establishes a legally binding obligation for all business entities meeting specified requirements to identify and prevent adverse human rights and environmental impacts resulting from their own activities or activities linked to their activities. The law mandates business entities to practice human rights due diligence - they must establish, publish and implement a vigilance plan.

An overview of the CSR initiatives with the greatest emphasis on human rights is given in further sections.

\section{United Nations Global Compact Principles}

The UN Global Compact is the biggest global voluntary initiative on CSR, designed with the purpose of developing and disseminating CSR in the areas of human rights, labour, the environment and anti-corruption. It is intended for business entities willing to commit to aligning their policies and strategies with ten universally accepted principles derived from the Universal Declaration of Human Rights $1948,{ }^{52}$ the UN Convention against Corruption, ${ }^{53}$ the Rio Declaration on Environment and Development $1992^{54}$ and the ILO Declaration on Fundamental Principles and Rights at Work. ${ }^{55}$

The UN Global Compact Principles relating to human rights stipulate that business entities should support and respect the protection of internationally proclaimed human rights (Principle 1); and ensure they are not complicit in human rights abuses (Principle 2). When business entities respect human rights, the rule of law is promoted, consumer perception of working conditions is improved, the management supply chain is strengthened, employee productivity is increased, and good relationships with the community are formed.$^{56}$ The UN Global Compact Principles do not only require business entities to respect human rights but also to support and protect them ${ }^{57}$ by taking positive steps to promote and advance them. They also give guidance to business entities on how to reduce their risk of involvement or complicity in human rights abuses. The human rights commitments set out in the Principles are entirely in line with the responsibility to respect human rights contained in the second pillar of the UN GPs. ${ }^{58}$

\footnotetext{
52 GA Res 217A (III), UN Doc A/810.

${ }^{53} \mathrm{UN}$ Doc A/58/422.

${ }^{54}$ A/CONF.151/26 (Vol. I).

${ }^{55}$ UN Global Compact (2017a).

${ }^{56}$ UN Global Compact (2017b).

${ }^{57}$ UN Global Compact Principles therefore go beyond business entities' legal obligations.

${ }^{58}$ UN Global Compact and Office of the High Commissioner for Human Rights (2017).
} 


\section{ISO 26000}

In 2010, the International Organization for Standardization (ISO) published International Standard on Social Responsibility ISO 26000, the purpose of which is to provide business entities with guidance on social responsibility; help them integrate, implement and promote socially responsible behaviour; and contribute to sustainable development. ${ }^{59}$ The Standard applies to seven areas of social responsibility: organizational governance, human rights, labour practices, the environment, fair operating practices, consumer issues, and community involvement and development.

ISO 26000 states that organisations should respect human rights set out in the International Bill of Human Rights and acknowledge their importance and universality. ${ }^{60}$ In order to achieve this, organisations should adopt appropriate measures for respecting human rights. 61

Chapter 6.3, which is entirely dedicated to human rights, deals with eight issues relating to human rights: due diligence; human rights risk situations; avoidance of complicity; resolving grievances; discrimination and vulnerable groups; civil and political rights; economic, social and cultural rights; and fundamental principles and rights at work. ISO 26000 sets out how organisations are expected to address each of these issues. The chapter is fully in accordance with the UN GPs.

\section{The OECD Guidelines for Multinational Enterprises}

In June 1976, OECD adopted the OECD Declaration on International Investment and Multinational Enterprises, incorporating the OECD Guidelines for Multinational Enterprises. These were updated in 2000 and 2011. The OECD Guidelines set out principles and standards for socially responsible activities in accordance with applicable laws and internationally recognised standards in the following areas: disclosure; human rights; employment and industrial relations; environment; combating bribery, bribe solicitation and extortion; consumer interests; science and technology; and competition and taxation. ${ }^{62}$ Before the most recent update, the OECD Guidelines only made vague reference to human rights, but the latest version includes a chapter devoted to human rights, fully in alignment with the UN GPs. ${ }^{63}$

Chapter 2 of the OECD Guidelines requires business entities to '(r)espect the internationally recognised human rights of those affected by their activities' (paragraph 2). Chapter 4 is wholly dedicated to human rights, and specifies the obligations on business entities. Unlike states, which have a duty to protect human rights, business entities are required, within the framework of internationally recognised human rights, the international human rights obligations of the countries in which they operate, as well

\footnotetext{
${ }^{59}$ ISO (2010).

${ }^{6} \mathrm{Ibid}, 13-14$

61 Ibid.

62 OECD (2011).

63 Addo (2014).
} 
as all relevant domestic laws and regulations, to meet their responsibility to respect human rights by having in place policies and processes in accordance with UN GPs. ${ }^{64}$

\section{European Union initiatives}

For a long time EU initiatives on CSR pushed human rights into the background. A renewed EU strategy 2011-14 for Corporate Social Responsibility finally recognizes 'the need to give greater attention to human rights, which have become a significantly more prominent aspect of CSR'. ${ }^{65}$ It expresses the EU support for the UN GPs and commits to supporting their implementation. The European Commission ${ }^{66}$ believes that better implementation of the UN GPs will contribute to greater success in meeting EU objectives on specific human rights issues and core labour standards. The Commission expressed its intention to work with business entities and stakeholders in 2012 to develop human rights guidance for a limited number of relevant industrial sectors, as well as guidance for small and mediumsized enterprises, based on the UN GPs, and to publish, by the end of 2012, a report on EU priorities for the implementation of the UN GPs, and thereafter issue periodic progress reports. ${ }^{67}$ The Commission further expressed its expectation that all European business entities would fulfil their corporate responsibility to respect human rights, as defined in the UN GPs, and gave EU member states time until the end of 2012 to develop national plans for the implementation of the UN GPs. ${ }^{68}$ In December 2012 the Commission published A Guide to Human Rights for Small and Medium-sized Enterprises. ${ }^{69}$ This was followed in June 2013 by three sector guides on Implementing the UN GPs, one for employment and recruitment agencies, one for the ICT sector, and the third for the oil and gas sector.

Human rights were also incorporated into Directive 2014/95/EU. Article 19a was added to Directive 2014/95/EU, requiring large public-interest undertakings, whose balance sheets showed an average of more than 500 employees during the financial year, to include a non-financial statement in their management reports. This statement must contain the information required for an understanding of the undertaking's development, performance, position, and impacts of its activities, in relation to, as a minimum, environmental, social and employee issues, respect for human rights, anti-corruption and bribery. The same applies to the consolidated non-financial statement, regulated by Article 29a. The purpose of this change was to ensure a level playing field for enterprises on a European level. ${ }^{70}$

\section{Analysis of CSR Initiatives Introduced}

The adoption of the UN GPs led to international CSR initiatives to regulate human rights in a business context in a similar way. The UN Global Compact Principles, ISO 26000 and the OECD Guidelines for Multinational Enterprises all have a special chapter dedicated to

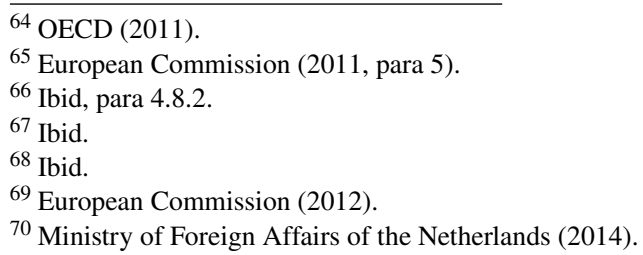


human rights and regulate human rights in business in accordance with the requirements of the UN GPs. Following the adoption of the UN GPs, EU CSR initiatives also focused their attention on human rights. Directive 2014/95/EU, with its requirement for the management report to include information on human rights issues, was a major step forward, putting pressure on business entities to respect human rights.

The findings from the theoretical part regarding the law were not confirmed in the studied CSR initiatives. As the CSR initiatives are non-binding, they do not give an answer regarding the legal nature of the BHR issues. The exception applies to Directive 2014/95/EU that imposes mandatory reporting regarding human rights respect and in this way creates an obligation for corporate respect of human rights. All other CSR initiatives make it a requirement for business entities to respect human rights; only the UN Global Compact Principles also require to support and protect human rights.

The findings regarding the content were confirmed. Human rights are only a small part of CSR; the scale of activities is narrower and mostly limited to negative activities to respect human rights. All the commitments to respect human rights are superficial, simply referring to internationally recognized human rights. Only ISO 26000 gives a detailed insight into a number of human rights issues. The analysis has shown that CSR initiatives lack clarity regarding human rights, and that human rights are still not at the heart of the CSR debate. Although all mention human rights, the commitments are too vague, and do not offer specific instructions for business entities on how to meet their human rights obligations.

The findings regarding the strategic approach in the implementation of these concepts were also confirmed - the approach is the same. The same strategic approach was established due to the UN GPs. All CSR initiatives require a due diligence procedure in accordance with the UN GPs. None of these initiatives gives any further instructions regarding respect for human rights; neither are there any sanctions in the event of human rights abuses. This is a great weakness of these initiatives, because without clear guidance as to how to act in relation to human rights and predefined sanctions, these initiatives cannot be effective in ensuring respect for human rights.

\section{Link between CSR and human rights in practice}

Business entities have acknowledged that they have responsibilities towards society. ${ }^{71}$ Especially the concept of CSR has become rather fashionable, particularly for public relations purposes. Business entities are keen to improve their image among potential stakeholders by publicly acknowledging the importance of CSR and stating the steps they are taking to achieve it. Unfortunately, the same does not apply for human rights. The author agrees with Wettstein $(2009,142)$ that human rights issues in the business context have for too long been neglected by scholars in the fields of both human rights and CSR.

\footnotetext{
${ }^{71}$ The majority of business entities in McBeth and Joseph (2005) and Obara's (2017) empirical study recognized that they have direct human rights responsibilities, while Kamminga's (2016) study showed that less than one per cent of business entities acknowledge that they have these responsibilities. Institute for Human Rights and Business's study (2011) found that there are still too few business entities seriously engaging in human rights.
} 
Based on the criteria from chapter IV the author will study the link between CSR and human rights in practice.

Regarding the law, the author agrees with Buhmann (2011) that the lack of clarity about the mandatory and voluntary aspects of CSR has caused confusion about the relationship between CSR and human rights. In a qualitative study involving 22 international business entities based in the United Kingdom (UK) Obara and Peattie (2017) found that human rights are understood as a 'vague, complex, abstract and conceptual' term; connected not to a domestic country but to the global arena and supply chain operations; concerning mostly employees and workplace commitments; associated with legislation, regulation and compliance; belonging mainly to the state and not business entities. CSR by contrast was understood by business entities either as voluntary and philanthropic measures or as 'a natural part of doing business'. ${ }^{72}$ The author carried out an empirical study ${ }^{73}$ into the level of respect for human rights in business entities in the RS, which included a section on CSR. The entities studied were all business entities based in the RS, of any size, sector, ownership and operational context. The sample consisted of large, medium-sized, small and micro-enterprises, and was limited to members of the Chamber of Commerce and Industry of Slovenia. It was evident from the answers that long-term stable and profitable enterprises in the Republic of Slovenia (RS) were aware of their CSR, and as many as 73 per cent of the respondents claimed to operate in a socially responsible way. When asked to define CSR, they included a range of actions, but did not associate it with human rights. It was also concluded from the answers that enterprises with CSR policies do not manage them in detail: they have general commitments to protect the environment and their employees, but no specific strategies to implement them in practice. On the other hand, 94 per cent of respondents believed that business enterprises should respect human rights in their operations. Of these, 70 per cent thought respect for human rights in their operations was a legal requirement, 18 per cent thought it was voluntary, two per cent thought it a moral obligation and four per cent thought it both a legal and a moral obligation. The fact that the majority of the enterprises surveyed were aware that respecting human rights was a legal requirement and not a matter of choice probably explains why they did not associate respect for human rights with CSR, since they viewed CSR as a purely voluntary matter.

Regarding the content, the Obara and Peattie (2017) study showed that business entities adopted both negative and positive responsibilities in terms of CSR commitments, while in terms of human rights commitments, business entities generally focused on negative responsibilities. The issues recognized as human rights were narrower in scope than CSR, with labour rights referenced most often, while the environment, community and product safety being rarely explicitly related to human rights. On this basis, it is clear that there

\footnotetext{
72 Obara and Peattie (2017).

${ }^{73}$ Empirical research was carried out between 19 November 2014 and 19 February 2015. The survey consisted of 44 questions, divided into five sets. It was based on the author's theoretical findings and then published in online form using a tool for online surveys. More than 4,800 direct invitations to participate in the survey were issued, with a further 15,000 issued indirectly. This resulted in 255 respondents, of which 152 withdrew before the start. Of the remaining 103 respondents, 57 partially completed the survey and 46 fully completed it. More details in Čertanec (2015).
} 
has not been enough awareness of the fact that many of the issues covered by CSR are actually human rights concerns. ${ }^{74}$ The weak association of human rights and CSR can also be attributed to the fact that, despite having been numerous CSR initiatives, these have not focused on human rights. From the results of the analysis, it is evident that most CSR initiatives include at least one internationally recognised human right, but the problem is that they are labelled as something else. Jenkins (2001, 21-2) conducted an empirical study analysing and comparing 148 codes of conduct adopted by business entities in the OECD inventory and specific mention of human rights was only in 25 per cent of codes. McBeth and Joseph (2005) carried out a study on corporate perceptions of human rights responsibilities in 17 multinational companies and found that many human rights issues relevant to the business realm were not identified as such by companies and many issues were seen as belonging to the CSR domain. Terms such as 'labour standards' or 'social issues' were often used instead of the term of human rights. ${ }^{75}$ Institute for Human Rights and Business (2011) and Obara ${ }^{76}$ also found that human rights issues were incorporated within other terms such as CSR and not as human rights per se. GRI (2008) analysis found that labour practices were most frequently addressed human rights issues ${ }^{77}$ and were often included in the social section of sustainability reports, without identifying them as human rights. Preuss and Brown (2012) conducted a study of the most successful business entities, ${ }^{78}$ and found that 57.1 per cent of them referred to human rights in their CSR policies; worryingly, however, 42.8 per cent of them did not specifically emphasise the human rights aspect. 31.6 per cent of the most successful business entities had established at least one policy on corporate social responsibility but did not refer to human rights in it meaning that one third of the most successful business entities recognised the importance of socially responsible behaviour, but did not associate it with human rights. ${ }^{79}$ This was also clear from the research conducted by the author in the $\mathrm{RS},{ }^{80}$ which analysed the internal policies of 15 randomly selected business enterprises. This analysis showed that all the enterprises studied had policies on CSR, but only three explicitly mentioned human rights in them. ${ }^{81}$ The policies of these three enterprises were limited to general strategic commitments relating to human rights, and did not specify any actions to be taken in connection with them. From this, the author concluded that the RS business enterprises studied were aware of their social responsibilities, but did not associate them with human

\footnotetext{
74 Wettstein (2009).

75 McBeth and Joseph (2005).

${ }^{76}$ Obara's study (2017) showed that the label of 'human rights' was viewed as controversial and abstract and therefore unsuitable for employees to comprehend and relate to in their activities. It demonstrated that it is better to incorporate human rights within other terms such as CSR as they are considered more positive and clear.

77 The same result originates from Wright and Lehr's (2006) analysis of human rights in corporate policies of 314 Global FORTUNE 500 companies.

78 The research was conducted among FTSE 100 constituent firms.

79 Preuss and Brown (2012).

${ }^{80}$ More details in Čertanec (2015).

81 This is consistent with Institute for Human Rights and Business's study (2011) that relatively few business entities have an explicit statement on human rights.
} 
rights. This is consistent also with the result of the above-mentioned empirical studies (McBeth and Joseph, Institute for Human Rights and Business, Obara, GRI).

Regarding the strategic approach, the Obara and Peattie (2017) study observed four types of business entities regarding the extent to which human rights were integrated and implemented within the existing CSR structures and business processes. Most common were CSR strategists that perceive human rights as an integral part of CSR and both are embedded within the core strategy and governance processes. ${ }^{82}$ The study revealed that for the most of the sample business entities, CSR shaped and influenced the development and management of human rights within business entities as they used their existing CSR knowledge and experience to address and talk about human rights. ${ }^{83}$ In order to be able to continue, it is necessary to combine and integrate these two debates. The UN GPs have made business entities aware of their potential to abuse human rights by their operations and therefore their responsibility to respect human rights, but business entities still do not associate this with CSR. The McCorquodale, Smit, Neely and Brooks (2017) study indicated that the process of implementing human rights due diligence is slow, occurs in stages, and there is a lack of coherent approaches across all the company's departments that results in a limited ability of business entities to undertake effective responses to information obtained when identifying human rights impacts. As Wettstein (2009) argues, integrating respect for human rights with CSR can bring many benefits for human rights, as the CSR approach is already well established, while the notion of human rights in a business context is only just beginning to be developed. The author agrees with Buhmann (2011) that CSR can contribute to improved implementation of relevant international human rights law in countries where it has not yet been applied, both within and beyond the EU. CSR will also bring progress in the acknowledgement of economic, social and cultural rights, which is currently lacking. While civil and political rights are internationally recognised and mostly properly implemented, the implementation of economic, social and cultural rights still lags behind. CSR policies that cover a range of economic, social and cultural rights will help to build a sense of their importance. Whilst business entities from different countries have different CSR policies, human rights represent a common ground between different cultural and moral traditions ${ }^{84}$ Here, a very important role will be played by business leaders - leaders who will understand the importance of moral behaviour and constant improvements in business environment. ${ }^{85}$ As Obara (2017) argues for successfully incorporation of human rights into management strategies there is a need to 'connect theory (what companies should do) with practice (what companies currently do or are willing to do in respect of human rights)'. Obara and Peattie (2017) believe that a true challenge for managers will be to use the existing CSR mechanisms to interpret and implement human rights in a way that the BHR issues will not be overlooked or 'buried' within CSR. The Obara and Peattie (2017) study found that the difference between CSR and human rights is not so great, therefore the CSR initiative

\footnotetext{
${ }^{82}$ Obara and Peattie (2017).

${ }^{83} \mathrm{Ibid}$.

${ }^{84}$ Wettstein (2012).

${ }^{85}$ Ibid.
} 
can offer a great starting point for broadening the human rights debate beyond its current 'do-no-harm' focus and for developing systems and processes through which action on human rights can be implemented and the BHR issues addressed.

\section{Conclusion}

CSR is a concept whereby business entities undertake to consider broader social goals in their operations, not just financial ones. One of these social goals is undoubtedly to respect the rights of stakeholders affected by their activities, i.e. human rights. The author therefore concludes that the terms CSR and human rights are interconnected: respect for human rights is a component part of CSR. The next significant question is to which extent the BHR issues are distinct from the CSR issues.

The BHR issues are distinct from the CSR issues in their legal nature and content. The BHR issues are mandatory (at least in an indirect way), while the CSR issues are mandatory only in the part where business entities should comply with the regulation. This could not be confirmed in the studied CSR initiatives because they are non-binding. The exception applies to Directive 2014/95/EU that imposes mandatory reporting regarding human rights respect and in this way creates an obligation for corporate respect of human rights. The empirical research in the RS showed that business entities do not associate CSR with human rights. This can be contributed to the fact that 70 per cent of business entities believe respect for human rights in their operations is a legal requirement, while they view CSR as a purely voluntary matter.

The CSR issues cover also the BHR issues, but they go further and demand proactive company involvement. This was confirmed in the studied CSR initiatives. The analysis has shown that human rights are only a small part of CSR; the scale of activities is narrower and mostly limited to negative activities to respect human rights. Although all CSR initiatives mention human rights, the commitments are too vague, and do not offer specific instructions for business entities as to how to meet their human rights obligations. Empirical researches (for example the Obara and Peattie study) showed that business entities adopted both negative and positive responsibilities in terms of CSR commitments, while in terms of human rights commitments, business entities generally focused on negative responsibilities. The issues recognized as human rights were narrower in scope than CSR, with labour rights referenced most often. On this basis, it is clear that there has not been enough awareness of the fact that many of the issues covered by CSR are actually human rights concerns. Therefore, caution is necessary that the CSR issues do not cloud over the BHR issues.

On the other hand, the strategic approach in the implementation of these concepts is the same; the distinction originates only from the difference in the content. This was confirmed in the studied CSR initiatives, since all require a due diligence procedure in accordance with the UN GPs. None of these initiatives gives any further instructions regarding respect for human rights; neither are there any sanctions in the event of human rights abuses. The Obara and Peattie (2017) study revealed that most of the sample business entities perceive human rights as an integral part of CSR and both are embedded within the core strategy and governance processes, while on the other hand the McCorquodale, Smit, 
Neely and Brooks (2017) study indicated that the process of implementing a human rights due diligence is slow, occurs in stages, and there is a lack of coherent approaches across all the company's departments. Business entities should have strategies on how to include the CSR and BHR issues into their operations and comply with them. The BHR issues can be included in CSR strategies, but they have to be clear and understandable.

In everyday business there is still not enough awareness that respect for human rights is an element of CSR. Business entities mostly associate CSR with actions that go beyond compliance with the law, and not with actions that are mandated by the law. Business entities see CSR as involving charitable donations, care for the environment, help for the local community, concern for employee welfare, etc. In their view, respect for human rights is only their duty inasmuch as it is mandated by national legislation. The fact that they do not associate the two is in large part attributable to the missing legally binding instrument that would express the connection between them. There are too many vague statements from international organisations: they lack a clear expression of the position. The OECD, UN Global Compact and similar initiatives stating that human rights are an aspect of CSR are all steps in the right direction. The main problem is that they do not state clearly, what is meant by respect for human rights. The adoption of the UN GPs and the adjustment of initiatives to bring them into alignment with them has resulted in a clearer understanding of what is meant by respect for human rights, but there are still many unanswered questions as to how to achieve it in practice.

Over time, changes in society will lead to changes in the legal regime, and legal regimes will need to adapt in order to reflect those social changes. ${ }^{86}$ Structural injustices will increasingly require different solutions as well as increased accountability on the part of business entities ${ }^{87}$ Increases in business entities' political and economic power have resulted in a bigger social role for them too. Respect for human rights is very much a part of the corporate remit, and business entities will have to play their part in the field of human rights protection and be aware of their responsibilities. As a result, the number of initiatives promoting CSR and respect for human rights will increase. The final step in linking CSR with respect for human rights will probably only be achieved once this connection has been clearly stated in a binding instrument. Only then will society finally acknowledge the connection between CSR and human rights.

\footnotetext{
${ }^{86}$ Buhmann (2011).

${ }^{87}$ Wettstein (2009).
} 


\section{References}

Addo, M. K. (2014). The Reality of the United Nations Guiding Principles on Business and Human Rights. Human Rights Law Review, 14(1), 133-147.

Arkani, S.; Theobald, R. (2005). Corporate involvement in human rights: is it any of their business? Business Ethics: A European Review, 14(3), 190-205.

Arnold, D. G. (2010). Transnational Corporations and the Duty to Respect Basic Human Rights. Business Ethics Quarterly, 20(3), 371-399.

Bilchitz, D. (2013). A chasm between 'is' and 'ought'? A critique of the normative foundations of the SRSG's Framework and the Guiding Principles. In Deva, S.; Bilchitz, D. (eds.). Human Rights Obligations of Business: Beyond the Corporate Responsibility to Respect? Cambridge: Cambridge University Press.

Buhmann, K. (2006). Corporate social responsibility: what role for law? Some aspects of law and CSR. Corporate Governance: The International Journal of Business in Society, 6(2), 188-202.

Buhmann, K. (2011). Integrating human rights in emerging regulation of Corporate Social Responsibility: the EU case. International Journal of Law in Context, 7(2), 139-179.

Campbell, T. (2006). A human rights approach to developing voluntary codes of conduct for multinational corporations. Business Ethics Quarterly, 16(2), 255-269.

Carasco, E. F.; Singh, J. B. (2008) Human Rights in Global Business Ethics Codes. Business \& Society Review, 113(3), 347-374.

Carroll, A. B. (1979). A Three-Dimensional Conceptual Model of Corporate Performance. The Academy of Management Review, 4(4), 497-505.

Carroll, A. B. (1991). The Pyramid of Corporate Social Responsibility: Toward the Moral Management of Organizational Stakeholders. Business Horizons, 34(4), 39-48.

Commission of the European Communities (2001, July 18). Green Paper: Promoting a European framework for corporate social responsibility, COM(2001)366.

Commission of the European Communities (2006, March 22). Communication from the Commission to the European Parliament, the Council and the European Economic and Social Committee - Implementing the partnership for growth and jobs: making Europe a pole of excellence on corporate social responsibility, $\mathrm{COM(2006)136} \mathrm{final.}$

Corporate Duty of Vigilance Law. (2017). Retrieved May 31, 2018, from http://www.respect.international/french-corporate-duty-of-vigilance-law-english-translation/.

Čertanec, A. (2015). Varstvo človekovih pravic pri delovanju gospodarskih subjektov po Smernicah Združenih narodov. Ljubljana.

Economic and Social Council (2006, February 22). Interim Report of the Special Representative of the Secretary-General on the Issue of Human Rights and Transnational Corporations and Other Business Enterprises', E/CN.4/2006/97.

Cragg, W. (2012). Ethics, Enlightened Self-Interest, and the Corporate Responsibility to Respect Human Rights: A Critical Look at the Justificatory Foundations of the UN Framework. Business Ethics Quarterly, 22(1), 9-36.

De la Vega, C.; Mehra, A. (2009). International Legal Accountability over Non-State Actors: An Analysis of the Report of the Special Representative of the Secretary General. Zeitschrift für Menschenrechte, 3(2), 26-40. 
Emeseh, E.; Songi, O. (2014). CSR, human rights abuse and sustainability report accountability. International Journal of Law and Management, 56(2), 136-151.

European Commission (2011, October 25). A Renewed EU Strategy 2011-14 for Corporate Social Responsibility, COM(2011)681.

European Commission (2012, November 30). My business and human rights: A guide to human rights for small and medium-sized enterprises. Retrieved July 31, 2017, from http://accessfacility.org/my-business-and-human-rights-guide-human-rights-smalland-medium-sized-enterprises.

European Parliament and Council (2014). Directive 2014/95/EU of the European Parliament and of the Council of 22 October 2014 amending Directive 2013/34/EU as regards disclosure of non-financial and diversity information by certain large undertakings and groups, OJ L 330/1.

GRI (2008). Reporting on Human Rights. Amsterdam: GRI.

GRI (2017). GRI Standards. Retrieved July 31, 2017, from www.globalreporting.org/standards.

GRI (2019). GRI 412: Human Rights Assessment. Retrieved March 1, 2019, from www.globalreporting.org/standards/gri-standards-download-center/gri-412-humanrights-assessment/.

Hsieh, N. (2015). Should Business Have Human Rights Obligations? Journal of Human Rights, 14(2), 218-236.

Human Rights Council (2011, March 21). Guiding Principles on Business and Human Rights: Implementing the United Nations "Protect, Respect and Remedy" Framework, A/HRC/17/31.

Institute for Human Rights and Business (2011). The 'State of Play' of Human Rights Due Diligence: Anticipating the Next Five Years. London: Institute for Human Rights and Business.

International Organization for Standardization (2010, November 1). ISO 26000 - Guidance on social responsibility. Retrieved July 31, 2017, from https://www.iso.org/iso-26000social-responsibility.html.

Fasterling, B.; Demuijnck, G. (2013). Human Rights in the Void? Due Diligence in the UN Guiding Principles on Business and Human Rights. Journal of Business Ethics, 116, 799-814.

Jenkins, R. (2001, April). Corporate Codes of Conduct Self-Regulation in a Global Economy. United Nations Research Institute for Social Development, Technology, Business and Society Programme Paper Number 2. Retrieved July 31, 2015, from www.unrisd.org/80256B3C005BCCF9/(httpAuxPages)/E3B3E78BAB9A886F80256B5E00344278/\$file/jenkins.pdf.

Kamminga, M. T. (2016). Company Responses to Human Rights Reports: An Empirical Analysis. Business and Human Rights Journal, 1(1), 95-110.

Kinley, D.; Tadaki, J. (2003-2004). From Talk to Walk: The Emergence of Human Rights Responsibilities for Corporations at International Law. Virginia Journal of International Law, 44(4), 931-1023.

Korže, B. (1993). Ustavni temelji podjetništva. Podjetje in Delo, 19 (5/6), 461-468. 
Korže, B. (2006). Do takeovers downgrade the contents of human rights and freedoms in EU? The IPSI BgD Transactions on Advanced Research, 2(1), 51-60.

Korže, B. (2014). Obligations of the social market state and business entities according to the EU guiding principles. International Journal of Business and Public Administration, 11(2), 1-22.

Letnar Černič, J. (2003). Mednarodnopravna odgovornost multinacionalnih družb za kršenje temeljnih človekovih pravic. Pamfil, 25-28.

Letnar Černič, J. (2009). Družbena odgovornost gospodarskih družb. Pravna praksa, 28(27), 9-11.

Letnar Černič, J. (2011). Corporate Human Rights Obligations: Towards Binding International Legal Obligations? Dignitas, 49/50, 55-104.

Lund-Thomsen, P. (2008). The Global Sourcing and Codes of Conduct Debate: Five Myths and Five Recommendations. Development and Change, 39 (6), 1005-1018.

Matten, D.; Moon, J. (2008). "Implicit" and "Explicit" CSR: A Conceptual Framework for a Comparative Understanding of Corporate Social Responsibility. Academy of Management Review, 33(2), 404-424.

McBeth, A. (2010). International Economic Actors and Human Rights. London, New York: Routledge.

McBeth, A.; Joseph, S. (2005). Same Words, Different Language: Corporate Perceptions of Human Rights Responsibilities. Australian Journal of Human Rights, 11(2), 95-127.

McCorquodale, R. (2009). Corporate Social Responsibility and International Human Rights Law. Journal of Business Ethics, 87, 385-400.

McCorquodale, R.; Smit, L.; Neely, S.; Brooks, R. (2017). Human Rights Due Diligence in Law and Practice: Good Practices and Challenges for Business Enterprises. Business and Human Rights Journal, 2(2), 195-224.

Ministry of Foreign Affairs of the Netherlands (2014). National Action Plan on Business and Human Rights. Hague: Ministry of Foreign Affairs.

Monshipouri, M. et al (2003). Multinational Corporations and the Ethics of Global Responsibility: Problems and Possibilities. Human Rights Quarterly, 25 (4), 965-989.

Muchlinski, P. (2001). Human rights and multinationals: is there a problem? International Affairs, 77 (1), 31-47.

Obara, Louise J. (2017). "What Does This Mean"?: How UK Companies Make Sense of Human Right. Business and Human Rights Journals, 2(2), 249-273.

Obara, L. J.; Peattie, K. (2017). Bridging the Great Divide? Making Sense of the Human Rights-CSR Relationship in UK Multinational Companies. Journal of World Business, 53(6), 781-793.

OECD (2011). OECD Guidelines for Multinational Enterprises. Retrieved July 31, 2017, from http://dx.doi.org/10.1787/9789264115415-en.

Pedersen, E. R.; Andersen, M. (2006). Safeguarding corporate social responsibility (CSR) in global supply chains: how codes of conduct are managed in buyer-supplier relationships. Journal of Public Affairs, (3/4), 228-240.

Porter, M. E.; Kramer, M. R. (2006). Strategy and Society: The Link Between Competitive Advantage and Corporate Social Responsibility. Harvard Business Review, 84(12), 78-92. 
Preuss, L.; Brown, D. (2012). Business Policies on Human Rights: An Analysis of Their Content and Prevalence Among FTSE 100 Firms. Journal of Business Ethics, 109(3), 289-299.

Rabet, D. (2009). Human Rights and Globalization: The Myth of Corporate Social Responsibility? Journal of Alternative Perspectives in the Social Sciences, 1(2), 463-475. Ramasastry, A. (2015). Corporate Social Responsibility Versus Business and Human Rights: Bridging the Gap Between Responsibility and Accountability. Journal of Human Rights, 14(2), 237-259.

Ruggie, J. G. (2013). Just Business: Multinational Corporations and Human Rights (1st ed.). New York and London: Norton.

Schwartz, M. S.; Carroll, A. B. (2003). Corporate Social Responsibility: A Three-Domain Approach. Business Ethics Quarterly, 13(4), 503-530.

Soh, C. (2013). Extending Corporate Liability to Human Rights Violations in Asia. Journal of International and Area Studies, 20(1), 23-38.

Steiner, J. F.; Steiner, G. A. (2003). Business, Government, And Society: A Managerial Perspective (10th ed). Boston: McGraw-Hill/Irvin.

Taylor, M. B. (2011). The Ruggie Framework: Polycentric regulation and the implications for corporate social responsibility. Nordic Journal of Applied Ethics / Etikk i praksis, 5(1), 9-30.

The Companies Act. (2013). Retrieved July 31, 2017, from www.mca.gov.in/Ministry/pdf/ CompaniesAct2013.pdf.

United Nations (1983, May 21). UN Draft Code of Conduct on Transnational Corporations, E/1983/17/Rev. 1 .

UN Global Compact (2017a). The Ten Principles of the UN Global Compact. Retrieved July 31, 2017, from https://www.unglobalcompact.org/what-is-gc/mission/principles.

UN Global Compact (2017b). Principle One: Human Rights. Retrieved July 31, 2017, from www.unglobalcompact.org/what-is-gc/mission/principles/principle-1.

UN Global Compact and Office of the High Commissioner for Human Rights (2017). The UN Guiding Principles on Business and Human Rights: Relationship to UN Global Compact Commitments. Retrieved July 31, 2017, from www.globalcompact.de/sites/default/files/jahr/publikation/UN GPs_gc_note.pdf.

United Nations: Office of the High Commissioner for Human Rights (2012, June). The Corporate Responsibility to Respect Human Rights: An Interpretive Guide, HR/PUB/12/ 02.

Van Huijstee, M. et al (2012, November). How to Use the UN Guiding Principles on Business and Human Rights in Company Research and Advocacy - A Guide for Civil Society Organisations. Retrieved March 1, 2016, from https://www.somo.nl/wpcontent/uploads/2012/11/English-version.pdf.

Weissbrodt, D. (2005). Business and Human Rights. University of Cincinnati Law Review, 74, 55-73.

Wettstein, F. (2009). Beyond Voluntariness, Beyond CSR: Making a Case for Human.

Rights and Justice. Business and Society Review, 114(1), 125-152. 
Wettstein, F. (2012). CSR and the Debate on Business and Human Rights: Bridging the Great Divide. Business Ethics Quarterly, 22(4), 739-770.

Wheeler, S. (2015). Global production, CSR and human rights: the courts of public opinion and the social licence to operate. The International Journal of Human Rights, 19(6), 757-778.

World Conference on Human Rights (1993, June 25). Vienna Declaration and Programme of Action, A/CONF.15/23.

Wright, M.; Lehr, A. (2006, December 12). Business Recognition of Human Rights: Global Patterns, Regional and Sectoral Variations. Corporate Social Responsibility Initiative. Retrieved July 31, 2017, from www.reports-and-materials.org/Business-Recognition-ofHuman-Rights-12-Dec-2006.pdf. 